Vol. 10 (2001): 223-229.

\title{
Reducing grain damage in naked oat through gentle harvesting
}

Anna-Maija Kirkkari

Work Efficiency Institute, PO Box 13, FIN-05201 Rajamäki, Finland, e-mail: anna-maija.kirkkari@tts.fi

Pirjo Peltonen-Sainio

MTT Agrifood Research Finland, Plant Production Research, FIN-31600 Jokioinen, Finland

Hannu Rita

Faculty of Agriculture and Forestry, PO Box 27, FIN-00014 University of Helsinki, Finland

\begin{abstract}
The caryopsis of naked oat is sensitive to mechanical damage at harvest, especially at high grain moisture content. For producing high quality naked oat seed, it is recommended that harvesting be carried out at as low grain moisture content as possible. This reduces mechanical damage to the grain and promotes germination. Under northern growing conditions, grains are often harvested at $20 \%$ moisture content or higher. In this study, reduced grain resulted from using gentler settings on the combine harvester. Two naked oat cultivars and one conventional oat were harvested at different grain moisture content using three combine harvester settings: the first setting that recommended for conventional oat, the second a reduced cylinder speed and the third a narrow concave clearance. The greater the grain moisture content of naked oat at harvest, the more damage was caused by threshing. Lower cylinder speeds tended to result in better germination than higher speeds, even under moist conditions. Narrowing the concave clearance did not affect germination.
\end{abstract}

Key words: naked oat, threshing, germination, moisture content, cylinder speed, concave clearance.

\section{Introduction}

Grain crops in Finland are often threshed when the moisture content of the grain is approximately 21-23\% (Aaltonen et al. 1999). Threshing and drying expose grains to mechanical stress and, particularly when threshed while moist, grains are damaged. The most vulnerable grains include those that thresh free from the lemma and palea, including wheat (Triticum aestivum L.), rye (Secale cereale L.) and naked oat (Avena sativa f. sp. nuda L.).

Naked oat is excellent from a nutritional point of view as it is characterised by a high energy content and a favourable combination of amino acids and minerals (Doyle and Valentine 1988, Valentine 1995, Särkijärvi et al. 2000). The fat- 


\section{Kirkkari, A.-M. et al. Grain damage of naked oat at harvest}

Table 1. Typical conventional raspbar cylinder settings for a range of crops (Stout and Cheze 1999).

\begin{tabular}{lcccc}
\hline & Peripheral & & \multicolumn{2}{c}{ Clearance } \\
\cline { 2 - 3 } Crop & Speed m/s & & Front mm & Rear mm \\
\hline Barley & $27-34$ & & $10-18$ & $3-10$ \\
Beans & $7-20$ & & $20-35$ & $10-18$ \\
Maize & $10-20$ & & $25-30$ & $15-20$ \\
Oats & $27-35$ & & $12-20$ & $3-10$ \\
Peas & $7-18$ & & $20-30$ & $10-18$ \\
Rapeseed & $15-24$ & & $20-30$ & $10-20$ \\
Rye & $25-35$ & $12-20$ & $3-10$ \\
Rice & $20-30$ & $14-18$ & $3-6$ \\
Wheat & $24-35$ & $12-20$ & $4-10$ \\
\hline
\end{tabular}

ty (7-9 \% oil content) grains (Saastamoinen 1989) are, however, soft, and harvest at a high moisture content further increases the softness of the grain. Mechanical injuries, such as contusions, scratches and bruises, also reduce germination through making the grains vulnerable to fungal infections that reduce storability and hamper further processing (Stout and Cheze 1999). Some injuries reduce the viability of the grain immediately (e.g., damage to the embryo), while others only become evident during storage (Moore 1972).

In the United Kingdom, it is advised that naked oat be threshed at grain moisture contents of less than $20 \%$ to prevent damage (Hayes 1992). Good germination is essential if the crop is to be used as seed or in food processing that requires germination, such as malting (OksmanCaldentey et al. 1999). Low germination does not, however, reduce the value of the crop as feed. However, sowing more seeds can compensate for reduced germination (Valentine and Hale 1990, Peltonen-Sainio 1997).

It is not possible to obviate weather conditions occurring at grain filling and harvesting but it is possible to select cultivars that mature prior to an unfavourable harvesting period. According to results from a study of wheat in Finland (Järvenpää 1992) grain damage incurred by threshing at high moisture content was reduced by adjusting the cylinder speed and concave clearance of the combine harvester. However Valentine and Hale (1990) found out that even using a low drum speed (850 rev $\mathrm{min}^{-1}$ ) germination above an $85 \%$ germination standard with naked oat could not be guaranteed. A reference value for cylinder speed and concave clearance has been determined for each crop species (Table 1, Stout and Cheze 1999). For naked oat, the aim is to maximise the yield free from lemma and palea and minimise threshing loss and grain damage. The higher the moisture content of the grain, the greater the impact of the cylinder speed on germination (Sitkei 1986, Stout and Cheze 1999). It is difficult to optimise threshing adjustments, as increased cylinder speed is needed to free the grain from the lemma and palea at high moisture content (Arnold 1964). A minimum cylinder speed of $20-24 \mathrm{~m} / \mathrm{s}$ is required to thresh naked oat free from lemma and palea (Hayes 1992). Results from earlier research suggested that the cylinder speed affects germination, but Thornton (1986) showed that adjustment of concave clearance did not significantly affect germination of naked oat when a Hege plot combine harvester was used. Results from another study indicated that concave clearance should, however, be set as wide as possible (Valentine and Hale 1990).

Thornton (1986) studied the structure of various oat cultivars and their ability to withstand mechanical damage. However, no very resistant naked oat was identified. Moreover, naked cultivars differed in embryo protrusion, which may contribute to grain damage, but there was no solid evidence that less protruding embryos were associated with improved germination ability. In trials conducted in Finland by Peltonen-Sainio et al. (2001) no clear correlation was established between embryo protrusion and proportion of normal seedlings. Nevertheless, large and hard grains are likely to be more susceptible to mechanical damage (Thornton 1986, Peltonen-Sainio et al. 2001), since they are likely to hit the thresher surfaces with greater force than small grains (Valentine and Hale 1990).

The present study compared the germination of two naked oat cultivars differing in suscep- 
Vol. 10 (2001): 223-229.

Table 2. Monthly mean temperature and precipitation for growing seasons 1998, 1999 and 2000 and long-term means (1961-1990) at Rajamäki (Ilmatieteenlaitos, personal communication with Pikko Karlsson by e-mail 5 March 2001).

\begin{tabular}{|c|c|c|c|c|c|c|c|c|}
\hline \multirow[t]{2}{*}{ Month } & \multicolumn{4}{|c|}{ Mean temperature $\left({ }^{\circ} \mathrm{C}\right)$} & \multicolumn{4}{|c|}{ Precipitation $(\mathrm{mm})$} \\
\hline & 1998 & 1999 & 2000 & Long-term & 1998 & 1999 & 2000 & Long-term \\
\hline May & 10.4 & 8.0 & 10.8 & 9.9 & 59 & 6 & 20 & 34 \\
\hline June & 14.4 & 18.4 & 14.4 & 14.9 & 120 & 29 & 39 & 52 \\
\hline July & 16.2 & 19.1 & 16.9 & 16.6 & 115 & 28 & 81 & 74 \\
\hline August & 13.6 & 15.4 & 15.4 & 15.0 & 95 & 34 & 91 & 83 \\
\hline September & 11.5 & 12.8 & 9.7 & 10.0 & 31 & 41 & 8 & 64 \\
\hline
\end{tabular}

tibility to mechanical injuries when threshed under different grain moisture content with that of conventional oat. Furthermore, effects of thresher adjustments to varying grain moisture on germination, cylinder speed and concave clearance.

\section{Material and methods}

The oat grains for the germination tests were cultivated between 1998 and 2000 in southern Finland at the Experimental Farm of the Work Efficiency Institute, Rajamäki. Two naked oat cultivars, Lisbeth and Bullion, and the husked cultivar Salo were grown. Each of the three oat cultivars was sown on three occasions at 3-6 day intervals in order to achieve maximum variation in moisture content during threshing. There were nine $250 \mathrm{~m}^{2}$ plots in total. The first sowing in 1998 was on 19 May (second on 22 May, third on 28 May), the first in 1999 on 11 May (second on 17 May, third on 20 May), and in 2000, the first on 3 May (second on 10 May, and third on 16 May). The field plots were sown and threshed with standard farm machinery. The sowing density was 550 viable seeds per square meter for naked oat and 500 seeds per square meter for conventional oat. The field plots received a basal fertilizer dressing $\left(450 \mathrm{~kg} \mathrm{ha}^{-1}\right.$ with NPK, 20-4-9, $\mathrm{N}$ as $\mathrm{NH}_{4} \mathrm{NO}_{3}$ ); weeds were controlled with a mixture of MCPA (a.i. $450 \mathrm{~g} \mathrm{ha}^{-1}$ ) and triasulfuron (a.i. $4 \mathrm{~g} \mathrm{ha}^{-1}$ ) and aphids were con- trolled with dimethoate (a.i. $200 \mathrm{~g} \mathrm{ha}^{-1}$ ) as necessary.

The weather conditions differed markedly during the cultivation years (Table 2). The weather in 1998 was cool and during the beginning of the growing season and early grain-filling period it was exceptionally rainy. The first threshing was carried out on 7 September. The conditions in 1999 were completely contrary to those in 1998 and the first harvest was on 4 August. The growing conditions in 2000 favoured yield formation and harvesting began on 30 August. To guarantee variation in grain moisture content, several rounds of threshing were carried out, including both morning threshing (aiming at the highest possible moisture content after night) and afternoon threshing (aiming at the lowest possible moisture content). The crop from each plot was threshed three to seven times depending on the weather at harvesting and the consequent variation in grain moisture content. The grain moisture at harvest in 1998 ranged between $20 \%$ and $44 \%$, in 1999 between $15 \%$ and $37 \%$, and in 2000 between $16 \%$ and $28 \%$.

In 1998, the adjustments to the combine harvester (Claas Mercator 60) were as recommended in the user manual for threshing conventional oat. Thus, the cylinder (diameter $450 \mathrm{~mm}$ ) speed was $1200 \mathrm{rpm}(28 \mathrm{~m} / \mathrm{s})$ with the front concave clearance set at $18 \mathrm{~mm}$ and the rear concave clearance at $7 \mathrm{~mm}$. In 1999 two cylinder speeds were used, $1200 \mathrm{rpm}(28 \mathrm{~m} / \mathrm{s})$ and 900 $\mathrm{rpm}(21 \mathrm{~m} / \mathrm{s})$. In 2000, the concave clearance was reduced, with the front concave clearance setting at $15 \mathrm{~mm}$ and the rear at $5 \mathrm{~mm}$. 
Control grain samples were gathered by hand from each plot before threshing and they were hand threshed after gentle drying. Controls were used to ensure that no other factor (such as field sprouting) had influenced the germination prior to threshing. After each threshing round, a sample of approximately $3 \mathrm{~kg}$ of grain was taken from the tank of the combine harvester. To analyse the grain moisture, $10 \mathrm{~g}$ of whole grain was dried at $130^{\circ} \mathrm{C}$ for 19 hours. After harvesting, the samples were dried with cold air and the germination analyses were carried out approximately four months after harvesting. Germination analyses $(4 \times 100$ seeds on blotting paper) were made at the Plant Production Inspection Centre. Germination was classified in four replicates as normal, abnormal or non-viable. Only normally germinating grains with undamaged radicles and hypocotyls were included in the germination percentage.

\section{Statistical analyses}

The effect of grain moisture on germination was analysed using linear regression. To keep the interpretation clear, the germination percentages were left untransformed. The residuals were inspected for normality. The statistical tests were performed within an ANCOVA framework, with grain moisture as the covariate and cultivar and threshing as factors. The data for each year were analysed separately. The analyses were performed using SAS GLM-procedure, version 8.

\section{Results and discussion}

\section{The effect of grain moisture at harvest on germination capacity}

The greater the grain moisture content of naked oat at harvest, the more damage was caused by threshing (Fig. 1). Using standard adjustments, when the grain moisture increased by a single percentage point, the germination of the naked oat cultivar Lisbeth decreased by $1.9 \%$. Similarly, the germination of the naked oat cultivar Bullion decreased $2.3 \%$ points. Threshing was considered the primary reason for reduced germination since hand-threshed control samples of all cultivars retained reasonably high levels of germination $(100 \%$ to $86 \%)$ irrespective of grain moisture content at harvesting. Contrary to the results of Peltonen-Sainio et al. (2001), grain of conventional oat also suffered from harvesting at high moisture content, although the effect was less marked than with naked oats. The germination of the conventional cultivar Salo fell $0.6 \%$ for each unit increase in grain moisture content.

There were large differences in weather conditions during the course of these studies, especially during 1998 (data not shown). That year was characterized by high humidity at harvest, when the highest germination percentage for naked oat was less than $80 \%$. As the grain moisture content at harvest increased, germination decreased to below $30 \%$. In 1999, precipitation was low and the germination of naked oat under

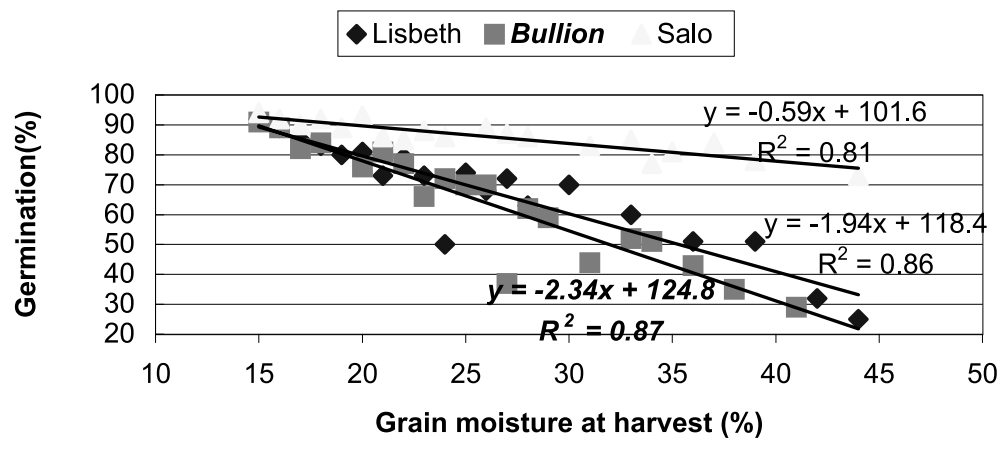

Fig. 1. The germination percentage of combine harvested naked cultivars (Lisbeth and Bullion) and husked Salo at grain moisture ranging from $15 \%$ to $44 \%$ (cylinder speed $28 \mathrm{~m} / \mathrm{s}$, concave clearance $18-7 \mathrm{~mm}$ ). 
Vol. 10 (2001): 223-229.

recommended threshing settings for conventional oat exceeded $90 \%$ and did not drop below $55 \%$, even when the highest moisture content at harvesting was $37 \%$. The germination of naked oat in the favourable growing season of 2000 ranged between $89 \%$ and $70 \%$ using standard harvesting methods.

If the germination requirement for naked oat for seed production is taken to be the $85 \%$, so it require with other cereals, this can only be achieved under very dry harvesting conditions, as shown by Peltonen-Sainio et al. (2001). According to results from these trials, the samples harvested at $<17 \%$ moisture content germinated at average $85 \%$ if the standard threshing adjustments were used (cylinder speed $1200 \mathrm{rpm}$, concave clearance $18-7 \mathrm{~mm}$ ). If the germination requirement were to be lowered to $75 \%$ (Valentine and Hale 1990), following the example of Great Britain and Finland during the last two years, this could be achieved at $<22 \%$ grain moisture content at harvesting. This would be a more realistic goal under Scandinavian conditions.

\section{The impact of thresher adjustments on germination}

There was a tendency for germination to be maintained better at the lower cylinder speed (900 rpm, $21 \mathrm{~m} / \mathrm{s}$ ), even under moist conditions. The naked oat cultivar Bullion tended to have $10 \%$ units higher germination rate at lower cylinder speeds when grain moisture content was $20 \%$ and even $22 \%$ units higher germination when moisture content exceeded over $30 \%$. For cultivar Lisbeth, germination was eight percentage points higher at lower cylinder speeds when grain moisture content was $18 \%$, and nine percentage points higher germination when grain moisture content was $26 \%$. The reason for this smaller effect with cultivar Lisbeth may be its relatively small grain size (Peltonen-Sainio et al. 2001), and the associated better ability to survive threshing compared with cultivar Bullion (Fig. 2). Overall, the results of maintaining bet-
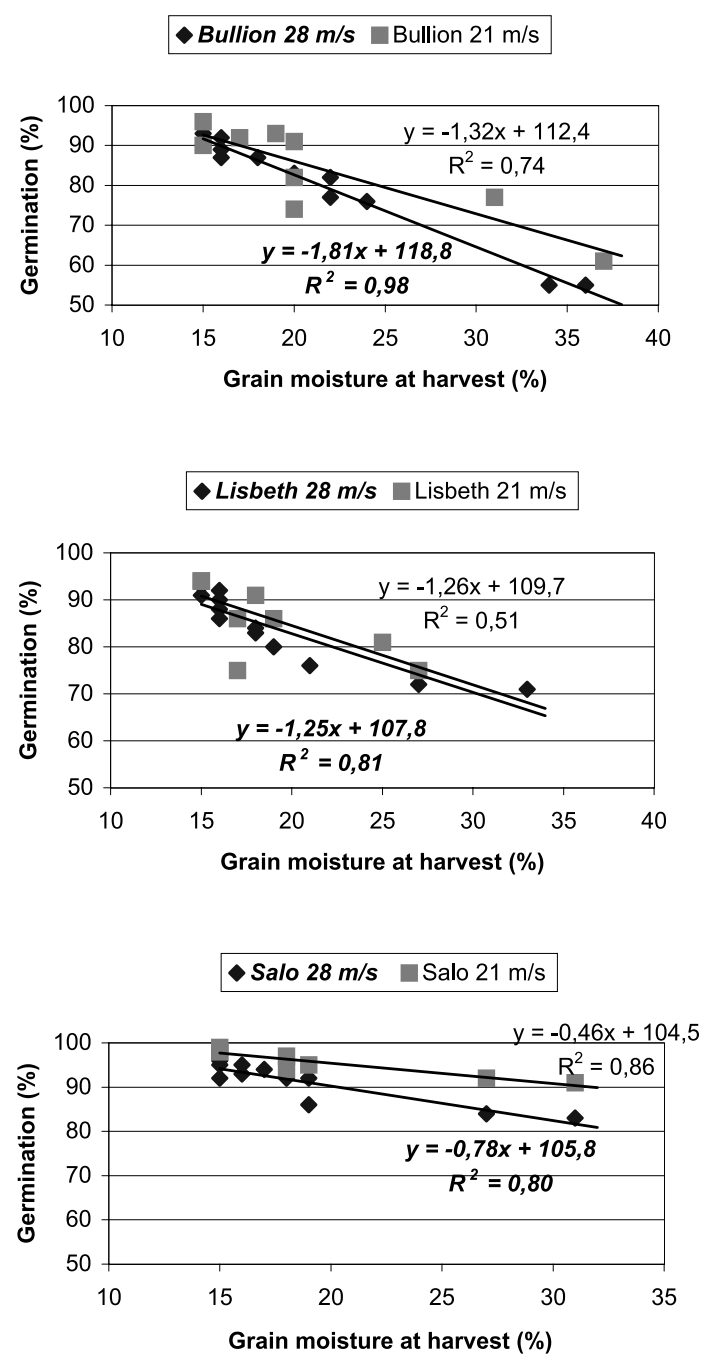

Fig. 2. Germination as function of threshing moisture and cylinder speed $(28 \mathrm{~m} / \mathrm{s}$ or $21 \mathrm{~m} / \mathrm{s})$ with naked cultivars Lisbeth and Bullion and husked Salo (concave clearance always 18-7). The regression lines are shown in the figure. The reaction of germination the threshing moisture does not depend on the threshing method within the cultivars $(\mathrm{P}$-value $=0.5289, \mathrm{df}($ degrees of freedom $)=2, \mathrm{df}=50)$. However, different cultivars react in different ways to changes in threshing moisture $(\mathrm{P}=0.0001, \mathrm{df}=2,50 ; t$-tests Salo vs. Bullion $\mathrm{P}<0.0001$, Salo vs. Lisbeth $\mathrm{P}=0.0112$ ).

ter germination at lower cylinder speeds were not statistically significant $(P>0.17)$ and further research is needed to determine whether cylinder speed could be lowered even more with- 
Kirkkari, A.-M. et al. Grain damage of naked oat at harvest
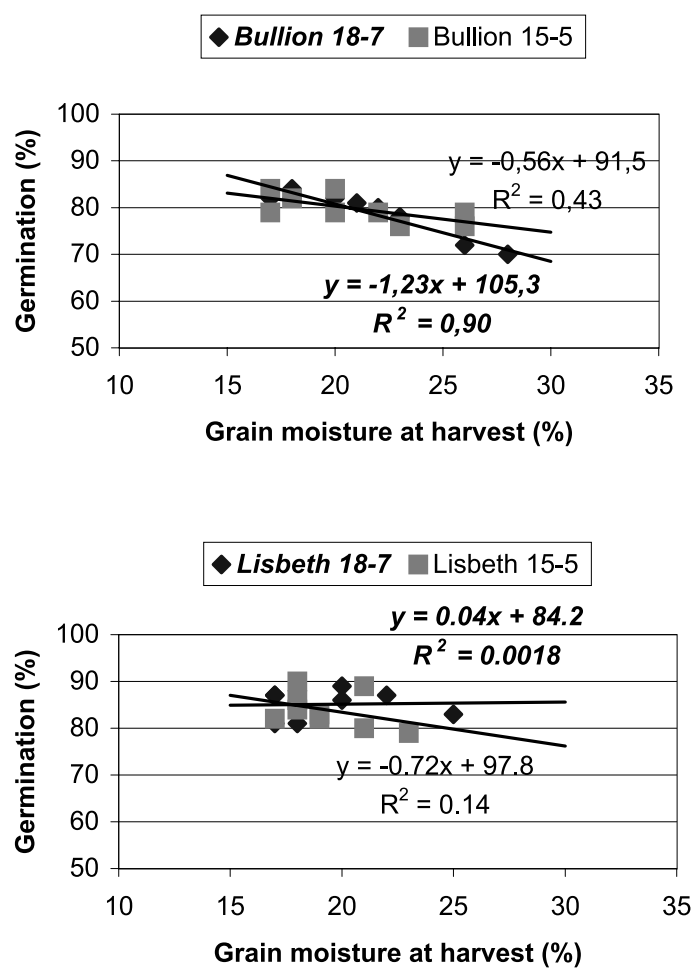

Salo 18-7 Salo 15-5

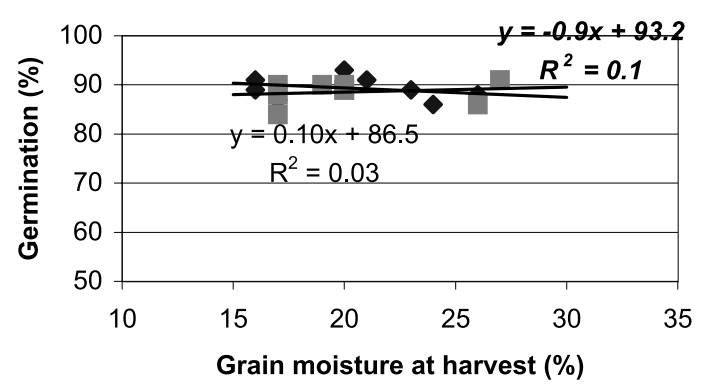

Fig. 3. Germination on the basis of threshing moisture and narrowing concave clearance ( 18 front -7 rear, 15 front 5 rear) with naked cultivars Lisbeth and Bullion and husked Salo (cylinder speed always $28 \mathrm{~m} / \mathrm{s}$ ). The regression lines are shown in the figure. The reaction of germination the threshing moisture does not depend on the threshing method within the cultivars $(P=0.1100, \mathrm{df}=2, \mathrm{df}=50)$. However, different cultivars react in different ways to changes in threshing moisture $(\mathrm{P}=0.0091, \mathrm{df}=2,42 ; t$-tests Salo vs. Bullion $\mathrm{P}=0.0015$, Salo vs. Lisbeth $\mathrm{P}=0.644$ ). out increasing markedly threshing losses. Furthermore, research is also needed into how increased grain moisture at harvest affects the process of threshing the grain free from the lemma and palea.

Narrowing the concave clearance from $18 \mathrm{~mm}$ to $15 \mathrm{~mm}$ at the front and from $7 \mathrm{~mm}$ to $5 \mathrm{~mm}$ at the rear did not significantly affect germination ( $\mathrm{P}=0$,9637) (Fig. 3). This was the case for all cultivars. The result is supported by earlier findings with naked oat (Thornton 1986) and wheat (Järvenpää 1992). Despite the recommendation that naked oat be threshed using as wide a concave clearance as possible, it does not seem to affect markedly subsequent germination. In our trials the concave clearance was set within the recommended levels (cf. Table 1), and narrowing the concave clearance from these settings would most likely result in reduction in germination. A wide concave clearance does not represent a disadvantage as long as it does not affect the amount of grain threshed free of lemma and palea.

\section{Conclusion}

On the basis of these results threshing a naked oat crop at a low as possible grain moisture content can reduce harvesting damage. However, if this is not possible, better germination can be ensured by reducing the cylinder speed. It should be borne in mind that a high germination percentage may only be necessary for seed material or if the grain is to be used in particular food processing. For seed production, it is also possible to compensate for the reduction in germination by increasing the amount of seeds sown. When producing naked oat for feed, germination capacity is not important.

Acknowledgements. The study was funded by Finnish Ministry of Agriculture and Forestry. The authors are grateful to the technical staff at Work Efficiency Institute, Plant Production Inspection Centre, and Plant Production Research unit at MTT Agrifood Research Finland for their valuable contribution. 
Vol. 10 (2001): 223-229.

\title{
References
}

Aaltonen, J., Järvenpää, M., Klemola, E. \& Laurila, I.P. 1999. Viljan korjuu-, kuivaus- ja logistiikkakustannukset Suomessa. Maatalouden taloudellisen tutkimuslaitoksen selvityksiä 2/99. 22 p.

Arnold, R.E. 1964. Experiments with Rasp Bar Threshing Drums. 1. Some Factors Affecting Performance. Journal of Agricultural Engineering Research 9, 2: 99-131.

Doyle, C.J. \& Valentine, J. 1988. Naked oats: an assessment of economic potential for livestock feed in the United Kingdom. Plant Varieties and Seeds (1988) 1: 99-108.

Hayes, J. 1992. Naked Oats - Growers' Note, $2^{\text {nd }}$. The Superioat Company Limeted. 34 p.

Järvenpää, M. 1992. Korjuutekniikan vaikutus kevätvehnän itävyyteen. Työtehoseuran julkaisuja 327. 107 p.

Moore, R.P. 1972. Effects of Mechanical Injuries on Viability. In: Roberts, E.H. (ed.). Viability of Seeds. Chapman and Hall LTD, London, UK. p. 95-111.

Oksman-Caldentey, K.-M., Laitila, A., Wilhelmson, A., Heiniö, R.-L., Outinen, M., Kaukovirta-Norja, A., Lehtinen, P., Plaami, S., Sontag-Strohm, T., Mikola, M. \& Poutanen, K. 1999. Kaura elintarvikeraaka-aineena. VTT's Research notes. Libella painopalvelu Oy, Espoo. 120 p.

Peltonen-Sainio, P. 1997. Groat yield and plant stand structure of naked and hulled oat under different nitrogen fertilizer and seeding rates. Agronomy Journal 89: 140-147.
-, Muurinen, S., Vilppu, M., Rajala, A., Gates, F. \& Kirkkari, A.-M. 2001. Germination and grain vigour of naked oat in response to grain moisture at harvest. Journal of Agricultural Science Cambridge (In press).

Saastamoinen, M. 1989. Kaurasta terveyskasvi kasvinjalostuksen keinoin. In: Pulli, S. et al. (eds.). Maataloustieteen päivät, Helsinki, 8-9.3.1989. Suomen maataloustieteellisen seuran tiedote no 12. p. 162-165.

Särkijärvi, S., Kajanto, L. \& Saastamoinen, M. 2000. Hevosten ruokinnassa vehnä parhaiten sulavaa - kaura pitää silti pintansa. Koetoiminta ja käytäntö. 57 vuosikerta, 3: 3.

Sitkei, G. 1986. Mechanics of Agricultural Materials. In: Developments in Agricultural Engineering 8. Amsterdam. 487 p.

Stout, B.A. \& Cheze, B. (eds.). 1999. Plant Production Engineering. In: CIGR Handbook of Agricultural Engineering. Volume 3. American Society of Agricultural Engineers. p. 311-347.

Thornton, M.S. 1986. Investigations into the problems associated with the development of naked oats as a crop. PhD Thesis, University of Wales, Aberystwyth.

Valentine, J. 1995. Naked oats. In: Welch R.W. (ed.), The Oat Crop. Chapman \& Hall, London, UK. p. 504-527.

- \& Hale, O.D. 1990. Investigations into reduced germination of seed of naked oats. Plant Varieties and Seeds 3: $21-30$.

\section{SELOSTUS}

\section{Paljasjyväisen kauran hellävarainen sadonkorjuu}

\author{
Anna-Maija Kirkkari, Pirjo Peltonen-Sainio ja Hannu Rita \\ Työtehoseura, MTT (Maa- ja elintarviketalouden tutkimuskeskus) ja Helsingin yliopisto
}

Paljasjyväinen kaura on altis sadonkorjuun aikaisille itävyysvaurioille varsinkin kun sato joudutaan puimaan kosteana. Työtehoseuran koetilalla Rajamäellä testattiin paljasjyväisellä kauralla puinnin aiheuttamia itävyysvaurioita eri puintikosteuksissa vuosina 19982000. Kun puintikosteus lisääntyi, paljasjyväisen kauran itävyys heikkeni enemmän kuin tavanomaisen kauran. Kosteana puitujen paljasjyväisten kaurojen itävyys oli lähes 20 prosenttiyksikköä alempi kuorelliseen kauraan verrattuna. Itävyysvaurioita pystyttiin alentamaan paljasjyväisellä kauralla vähentämällä puintikelan kierrosnopeutta 1200 kierroksesta/min $(28 \mathrm{~m} / \mathrm{s}) 900$ kierrokseen $(21 \mathrm{~m} / \mathrm{s})$. Saatu tulos ei kuitenkaan ollut tilastollisesti merkitsevä. Puintivälin kiristämisellä ei sen sijaan ollut vaikutusta itävyystuloksiin. Tulosten perusteella paljasjyväinen kaura on puitava mahdollisimman kuivana (alle $20 \%$ kosteudessa) itävyyden säilyttämiseksi. Puintikelan kierrosnopeutta alentamalla itävyysvaurioita voidaan välttää korkeammissakin kosteuksissa. 